УДК $342.9 ; 314.742$

DOI https://doi.org/10.32837/apdp.v0i90.3217

В. І. Палько

\title{
ОСОБЛИВОСТІ ПРАВОВОГО РЕГУЛЮВАННЯ ЗАБОРОНИ В’ЇЗДУ В УКРАЇНУ ІНОЗЕМЦІВ ТА ОСІБ БЕЗ ГРОМАДЯНСТВА
}

Постановка проблеми. Питання ефективності адміністративно-правових підстав заборони в'їзду іноземців та осіб без громадянства в Україну має важливе значення для забезпечення національної безпеки України, охорони громадського порядку; охорони здоров’я, захисту прав і законних інтересів громадян України та інших осіб, які проживають в Україні.

У цьому сенсі особливої актуальності набуває дослідження процесуальної форми прийняття рішень про обмеження в’їзду в Україну нелегальних мігрантів. Тим більше, якщо йдеться про їх повернення в країну громадянства або постійного чи тимчасового проживання, де їх життю або свободі загрожуватиме небезпека за ознаками раси, віросповідання, національності, громадянства (підданства), належності до певної соціальної групи або політичних переконань.

Стан дослідження. У зазначеній публікації аналізуються праці вчених, у яких досліджувалися питання примусового видворення іноземців, осіб без громадянства, адміністративної відповідальності, нелегальної міграції та правового статусу. Це праці О.М. Бандурки, Ю.П. Битяка, М.К. І.П. Голосніченка, Н.П. Демчик, А.Т. Комзюка, Ю.С. Кузьменка, Ю.С . А.Ф. Моти та ін.

Питання правового регулювання інституту заборони в'їзду іноземцям та особам без громадянства і їх видворення у зв’язку з невиконанням судових рішень і рішень інших юрисдикційних органів як спосіб впливу державного виконавця на боржника під час примусового виконання рішення, ускладненого іноземним елементом, стали предметом досліджень О.М. Мальського (2015 р.) [11].

Однак комплексного наукового дослідження правового регулювання заборони в’їду іноземців та осіб без громадянства в Україну не проведено.

Мета статті полягає в розкритті змісту правового регулювання заборони в’їзду іноземців та осіб без громадян в Україну, повернення або видворення їх за межі держави у зв'язку з наявними підставами, що передбачені в законодавстві України.

Виклад основного матеріалу. На сьогодні неврегульована (незаконна) міграція є одним із факторів загрози національній безпеці України, охороні громадського порядку, захисту прав і законних інтересів громадян України та інших осіб, які проживають в Україні. Крім того, вона загрожує і міжнародній безпеці та контролюється транснаціональною організованою злочинністю.

У результаті правоохоронним органам України доводиться боротися з цим негативним явищем.

Відповідно до п. 8 ст.19 Закону України «Про державну прикордонну службу України» на Державну прикордонну службу України покладаються завдання щодо запобігання та недопущення перетинання державного кордону України особами, яким згідно із законодавством не дозволяється в'їзд в Україну або яких тимчасово

(C) В. I. Палько, 2021 
обмежено у праві виїзду з України, у тому числі згідно з дорученнями правоохоронних органів, постановами державного виконавця [4].

Так, за 2019 рік підрозділами Державної прикордонної служби України було затримано 25401 нелегальних мігрантів (із них за незаконне перетинання кордону - 1372 ), в 2020 році - 9280 (в т.ч. за незаконне перетинання кордону - 1072) нелегальних мігрантів. Крім того, у 2019 році відмовлено в пропуску 10048 іноземцям - потенційним нелегальним мігрантам, в 2020 році - 5207 особам [9].

Аналіз статистичних даних Державної міграційної служби України (далі - ДМСУ) засвідчує, що у 2019 році територіальними підрозділами будо виявлено 12857 нелегальних мігрантів, а в 2020 році - 4199 таких осіб.

За три місяці 2021 року територіальними підрозділами ДМСУ виявлено 893 нелегальних мігрантів, що на 2,1 рази менше, ніж у 2019 році (1911). В Одеській області за аналогічний період виявлено 144 нелегальних мігранта в той же час у 2020 році - 327 таких осіб, тобто у 2,3 рази менше [10].

Це свідчить, що пандемія COVID-19 має значний вплив на мобільність незаконних мігрантів. В умовах, коли в багатьох країнах кордони закриті, сповільнилася і глобальна незаконна міграція. Не дивлячись на ці позитивні тенденції, окремі іноземці та особи без громадянства порушують міграційне законодавство України. За три місяці поточного року до адміністративної відповідальності було притягнуто 4344 правопорушників.

Абзацом першим статті 26 Конституції України встановлено, що іноземці та особи без громадянства, що перебувають в Україні на законних підставах, користуються тими самими правами і свободами, а також несуть такі самі обов'язки, як і громадяни України, за винятками, встановленими Конституцією, законами чи міжнародними договорами України [1].

Відповідно до статті 3 Закону України «Про правовий статус іноземців та осіб без громадянства» іноземці та особи без громадянства, які перебувають в Україні на законних підставах, користуються тими самими правами і свободами, а також несуть такі самі обов'язки, як і громадяни України, за винятками, встановленими Конституцією, законами чи міжнародними договорами України [5].

Іноземці та особи без громадянства, які перебувають під юрисдикцією України, незалежно від законності їх перебування, мають право на визнання їх правосуб'єктності та основних прав і свобод людини.

Отже, встановлення обмежень прав і свободи іноземців та осіб без громадянства можливе тільки на підстави Конституція та законів України.

Підстави для заборони в’їзду іноземців та осіб без громадянства в Україну зазначені в ст. 13 Закону України «Про правовий статус іноземців та осіб без громадянства». Водночас необхідно зазначити, що вказаний перелік підстав є вичерпним і розширеному тлумаченню не підлягає.

В’їзд в Україну іноземцю та особі без громадянства не дозволяється, зокрема:

1) в інтересах забезпечення національної безпеки України, або охорони громадського порядку, або боротьби з організованою злочинністю;

2) якщо це необхідно для охорони здоров'я, захисту прав і законних інтересів громадян України та інших осіб, які проживають в Україні; 
3) якщо при клопотанні про в’їзд в Україну така особа подала про себе завідомо неправдиві відомості або підроблені документи;

4) якщо паспортний документ такої особи, віза підроблені, зіпсовані чи не відповідають установленому зразку або належать іншій особі;

5) якщо така особа порушила у пункті пропуску через державний кордон України правила перетинання державного кордону України, митні правила, санітарні норми чи правила або не виконала законних вимог посадових та службових осіб органів охорони державного кордону, митних та інших органів, що здійснюють контроль на державному кордоні;

6) якщо під час попереднього перебування на території України іноземець або особа без громадянства не виконали рішення суду або органів державної влади, уповноважених накладати адміністративні стягнення, або існують інші не виконані майнові зобов'язання перед державою, фізичними або юридичними особами, включаючи пов'язані з попереднім видворенням, у тому числі після закінчення терміну заборони подальшого в’їзду в Україну;

7) якщо така особа з порушенням встановленого законодавством України порядку здійснила в’їзд на тимчасово окуповану територію України або до району проведення антитерористичної операції чи виїзд з них або вчинила спробу потрапити на ці території поза контрольними пунктами в’їзду-виїзду.

Аналогічні підстави для заборони в’їзду на територію України іноземцю викладені у Інструкції про порядок прийняття органами охорони державного кордону Державної прикордонної служби України рішень про заборону в’їзду в Україну іноземцям та особам без громадянства [6], Інструкції про порядок прийняття Державною міграційною службою України та ії територіальними органами рішень про заборону в'їзду в Україну іноземцям та особам без громадянства [8], Інструкції про порядок прийняття Службою безпеки України рішень про заборону в’їзду в Україну іноземцям та особам без громадянства [7].

Територіальними підрозділами Державної міграційної служби України в 2020 році відповідно до ст.13, 26 і 30 Закону України «Про правовий статус іноземців та осіб без громадянства» прийнято 4080 рішень про заборону в'їзду в Україну іноземцям та особам без громадянства. За чотири місяці поточного року прийнято таких рішень 1145 , в т.ч. Одеській області 183, Дніпропетровській області-148 та м. Києві - 125.

Рішення про заборону в’їзду в Україну строком на три роки приймається центральним органом виконавчої влади, що реалізує державну політику у сфері міграції(імміграції та еміграції), у тому числі протидії нелегальній (незаконній) міграції, громадянства, реєстрації фізичних осіб, біженців та інших визначених законодавством категорій мігрантів, Службою безпеки України або органом охорони державного кордону, або уповноваженим підрозділом Національної поліції України.

У разі невиконання рішення про заборону в’їзду в Україну іноземцям та особам без громадянства забороняється подальший в’їзд в Україну на десять років, що додається до частини строку заборони в'їзду в Україну, який не сплив до моменту прийняття повторного рішення про заборону в’їзду в Україну. 
З аналізу вищезазначених норм Закону України «Про правовий статус іноземців та осіб без громадянства» вбачається, що уповноважені органи державної влади (міграційні органи, органи Служби безпеки України, органи охорони державного кордону), приймаючи рішення про примусове повернення іноземця або особи без громадянства до країни походження, не зобов'язані одночасно приймати рішення про заборону в’їзду цієї особи на територію України.

Виходячи 3 конструкції правової норми, закріпленої в частині 2 статті 26 Закону України «Про правовий статус іноземців та осіб без громадянства», рішення про заборону подальшого в'їзду в Україну є не обов'язковим, а є факультативною санкцією, яка може застосовуватися під час прийняття рішення про примусове повернення в країну походження за наявності передбачених цим Законом підстав.

При цьому статтею 26 Закону України «Про правовий статус іноземців та осіб без громадянства» не визначено підстави для заборони в’їзду в Україну іноземцю або особі без громадянства, а лише передбачено можливість встановлення такої заборони строком на 3 роки у випадку прийняття рішення про примусове повернення.

Відповідно до ч. 2 ст. 19 Конституції України органи державної влади та органи місцевого самоврядування, їхні посадові особи зобов'язані діяти лише на підставі, в межах повноважень та у спосіб, що передбачені Конституцією та Законами України.

Аналіз судових рішень показав, що територіальні органи міграційної служби помилково ототожнюють підстави для примусового повернення іноземці та особи без громадянства в країну походження, визначені у частині 1 статті 26 Закону України «Про правовий статус іноземців та осіб без громадянства», з підставами для заборони його в’їзду в Україну.

Відповідно до підпункту «д» пункту 2.1 Інструкції про порядок прийняття органами охорони державного кордону Державної прикордонної служби України рішень про заборону в'їзду в Україну іноземцям та особам без громадянства визначено, що рішення про заборону в’їзду в Україну іноземцю приймається органом охорони державного кордону в разі якщо іноземця затримано у межах контрольованого прикордонного району під час спроби або після незаконного перетинання державного кордону України. Відповідно до ст. 9 Закону України «Про прикордонний контроль» прикордонний контроль іноземців та осіб без громадянства під час в’їзду в Україну здійснюється за процедурами контролю першої лінії, а у передбачених цим Законом випадках - також за процедурою контролю другої лінії.

Процедура здійснення контролю першої лінії передбачає проведення перевірки: 1) паспортного документа з метою встановлення його дійсності, наявності відповідно до вимог законодавства посвідки на постійне проживання чи візи; 2) наявності чи відсутності у базах даних Державної прикордонної служби України інформації про заборону в'їзду в Україну та про доручення правоохоронних органів щодо осіб, які перетинають державний кордон; 3) відміток про перетинання державного кордону в паспортному документі іноземця або особи без громадянства.

Пунктом 2.3 розділу 2 зазначеної Інструкції встановлено, що рішення про заборону в'їзду в Україну іноземцю органом охорони державного кордону приймається 
відповідно до Закону України «Про правовий статус іноземців та осіб без громадянства» на строк 3 роки. Строк заборони щодо подальшого в’їзду в Україну обчислюється з дня винесення такого рішення.

Наведене свідчить, що рішення про заборону подальшого в’їзду в Україну іноземців та осіб без громадянства не є обов'язковим до застосування під час прийняття рішення про примусове повернення в країну походження, а отже, є факультативною санкцією, яка може застосовуватись під час примусового повернення в країну походження цих осіб.

Встановлена частиною другою статті 26 Закону України «Про правовий статус іноземців та осіб без громадянства» можливість прийняття рішення про заборону подальшого в'їзду в Україну свідчить про наявність в органу Державної міграційної служби дискреційних повноважень.

Тобто, суб'єкту владних повноважень надається свобода, оцінюючи ситуацію, вибирати один із кількох варіантів можливих рішень. Правова позиція з цього питання викладена в постановах Верховного Суду від 13.03.2019 року в справі № 826/20228/16, від 13.06.2018 року в справі № 815/5991/15.

Необхідно звернути увагу на те, що іноземці та особи без громадянства, яким не дозволяється в’їзд в Україну, при спробі в’їзду в Україну в пункті пропуску через державний кордон України не перетинають державний кордон України та в найкоротший строк повертаються в державу, з якої вони прибули, або в державу, яка видала паспортний документ.

У випадку неможливості негайного повернення іноземця або особи без громадянства вони перебувають у пункті пропуску через державний кордон України до їх повернення.

Якщо ж іноземці та особи без громадянства в разі незаконного перетинання державного кордону України поза пунктами пропуску через державний кордон України затримуються та в разі, якщо порушення ними законодавства України не передбачає кримінальної відповідальності, повертаються до країни попереднього перебування у встановленому порядку.

Таким іноземцям та особам без громадянства органами охорони державного кордону забороняється в'їзд в Україну строком на п’ять років. Під час затримання органи охорони державного кордону забезпечують проведення дактилоскопії, а в разі потреби - взяття інших біометричних даних іноземців та осіб без громадянства відповідно до закону.

Висновки. Водночас, розглянувши основні проблемні питання, можна зазначити, що поняття терміна «заборона в’їзду іноземців та осіб без громадянства в Україну» в нормативно-правових актах не дається.

На наш погляд, заборона в’їзду іноземців та осіб без громадянства в Україну є заходами адміністративного попередження, як вид адміністративного примусу щодо цих осіб, з метою забезпечення національної безпеки України або охорони громадського порядку.

Із метою захисту прав і свобод та відповідно до міжнародного міграційного права Україна дотримується принципу заборони щодо примусового повернення чи примусового видворення або видачі чи передачі іноземця та особи без громадянства. 
Іноземець або особа без громадянства не можуть бути примусово повернуті чи примусово видворені або видані чи передані до країн: де їх життю або свободі загрожуватиме небезпека за ознаками раси, віросповідання, національності, громадянства (підданства), належності до певної соціальної групи або політичних переконань; де їм загрожує смертна кара або страта, катування, жорстоке, нелюдське або таке, що принижує гідність, поводження чи покарання; де їх життю або здоров’ю, безпеці або свободі загрожує небезпека внаслідок загальнопоширеного насильства в ситуаціях міжнародного або внутрішнього збройного конфлікту чи систематичного порушення прав людини, або природного чи техногенного лиха, або відсутності медичного лікування чи догляду, який забезпечує життя; де їм загрожує видворення або примусове повернення до країн, де можуть виникнути зазначені випадки.

Забороняється також колективне примусове видворення іноземців та осіб без громадянства. Крім того, існує нагальна проблема в удосконаленні правових підстав прийняття рішень про обмеження в’їзду іноземців та осіб без громадянства в Україну, що порушують міграційне законодавство.

\section{Jimepamypa}

1. Конституція України. Відомості Верховної Ради України. № 30. 1996. Ст. 141.

2. Про прикордонний контроль : Закон України від 5 листопада 2009 року № 1710-VI. Відомості Верховної Ради України (ВВР). 2010. № 6. Ст. 46.

3. Закон України «Про державний кордон України». Відомості Верховної Ради Украӥни. 1992. № 2. Ст. 5 .

4. Про Державну прикордонну службу України : Закон України від 3 квітня 2003 р. № 661-IV. Відомості Верховної Ради України (ВВР). 2003. № 27. Ст. 208.

5. Закон України «Про правовий статус іноземців та осіб без громадянства» від 22 вересня 2011 року. Офіційний вісник України. 2011. № 83. Ст. 3014.

6. Про затвердження Інструкції про порядок прийняття органами охорони державного кордону Державної прикордонної служби України рішень про заборону в'їзду в Україну іноземцям та особам без громадянства. Наказ Адміністрації Державної прикордонної служби України від 05.12.2011 № 946. Офіиійний вісник України. 2012. № 1, том 2. Ст. 43.

7. Про затвердження Інструкції про порядок прийняття Службою безпеки України рішень про заборону в’іззду в Україну іноземцям та особам без громадянства. Наказ Центрального управління Служби безпеки України від 29 січня 2021 року № 31. Офіційний вісник України. 2021. № 26. Ст. 1299.

8. Про затвердження Інструкції про порядок прийняття Державною міграційною службою України та ії територіальними органами рішень про заборону в'їзду в Україну іноземцям та особам без громадянства. Наказ Міністерства внутрішніх справ України від 17.12.2013 № 1235. Офіційний вісник України. 2014. № 9. Ст. 289.

9. Підсумки діяльності Державної прикордонної служби України за 2020 рік. URL: https://dpsu.gov.ua/ua/Pidsumki-za-2020-rik/ (дата звернення: 24.05.2021р.).

10. Статистичні дані Державної міграційної служби України за 2019-2021 роки. URL: https://dmsu.gov.ua/diyalnist/statistichni-dani.html (дата звернення: 24.05.2021).

11. Мальський М.М. Правове регулювання транснаціонального виконавчого процесу: заборона в'їзду й видворення іноземців та осіб без громадянства. Jurnalul Juriddic National: Teorie şi Practică. 2015. № 5(5). C. 122-126. URL: http://www.jurnaluljuridic.in.ua/archive/2015/5/part_1/25.pdf (дата звернення: 10.05.2021). 


\section{Анотація}

Палько В. І. Особливості правового регулювання заборони в’їзду в Україну іноземців та осіб без громадянства. - Стаття.

Метою статті є розкриття змісту правового регулювання заборони в’їзду іноземців та осіб без громадян в Україну, повернення або видворення їх за межі держави у зв'язку з наявними підставами, що передбачені в законодавстві України.

У статті наголошується, що неврегульована (незаконна) міграція є однією з головних проблем для України. Тому питання ефективності застосування правових підстав заборони в'їзду іноземців та осіб без громадянства в Україну має важливе значення для забезпечення національної безпеки України, охорони громадського порядку та боротьби з організованою злочинністю; охорони здоров'я, захисту прав і законних інтересів громадян України та інших осіб, які проживають в Україні.

Досліджуються також актуальні проблеми затримання іноземців та осіб без громадянства, які незаконно перетнули державний кордон України поза пунктами пропуску через державний кордон України, та повернення їх у державу, з якої вони прибули, або в державу, яка видалаїм паспортний документ.

Розглядаються правові підстави прийняття компетентними органами рішень про заборону в'їзду іноземців та осіб без громадянства та строки заборони в'їзду.

Аналіз правового регулювання заборони в'їзду іноземців та осіб без громадянства в Україну дають змогу зробити висновки про стан реалізації нормативно-правових актів, виявити прогалини в діяльності Державної міграційної служби України, Служби безпеки України, органів охорони державного кордону, як наслідок - запропонувати вирішення наявних проблем.

У статті аналізуються статистичні дані Державної міграційної служби України, Державної прикордонної служби України про заборону в’їзду в Україну іноземців та осіб без громадянства.

Акцентується увага щодо заборони примусового повернення чи примусового видворення або видачі чи передачі іноземця та особи без громадянства. Тим більше, якщо йдеться про їх повернення у країну громадянства або постійного чи тимчасового проживання, де їхньому життю або свободі загрожуватиме небезпека за ознаками раси, віросповідання, національності, громадянства (підданства), належності до певної соціальної групи або політичних переконань. Розглядаються питання оскарження прийнятих рішень про заборону в'їзду іноземців та осіб без громадянства в Україну.

Ключові слова: неврегульована міграція, правове регулювання, підстави для заборона в'їзду, іноземці, особи без громадянства, строки заборони, видворення.

\section{Summary}

Palko V.I. Features of the legal regulation of the ban on entry into Ukraine of foreigners and stateless persons. - Article.

The purpose of the article is to disclose the content of the legal regulation of the ban on entry of foreigners and stateless persons into Ukraine, return or deportation from the country in connection with the existing grounds provided by the legislation of Ukraine.

The article emphasizes that unregulated (illegal) migration is one of the main problems for Ukraine. Therefore, decision the problem of the effectiveness of the application of legal grounds for banning the entry of foreigners and stateless persons into Ukraine is important for ensuring the national security of Ukraine, protection of public order and the fight against organized crime; health care, protection of the rights and legitimate interests of citizens of Ukraine and other persons residing in Ukraine.

This article also researches the current problems of detention of foreigners and stateless persons who illegally crossed the state border of Ukraine outside the checkpoints across the state border of Ukraine and returned them to the state from which they arrived or to the state that issued them a passport and considers the powers competent authorities to decide on the entry of foreigners and stateless persons.

Analysis of the legal regulation of the ban on entry into Ukraine of foreigners and stateless persons will allow conclusions about the compliance with the rule of law, identify gaps in the activities of the State Migration Service of Ukraine, Security Service of Ukraine, State Border Service and, as a result, offer solutions to existing problems.

The article analyzes the statistical data of the State Migration Service of Ukraine, the State Border Guard Service of Ukraine on the ban on entry into Ukraine of foreigners and stateless persons.

Emphasis is placed on the prohibition of forcible return or forcible expulsion or extradition or transfer of a foreigner and a stateless person to a country of citizenship or permanent or temporary residence where their life or liberty will be endangered on the grounds of race, religion, nationality, citizenship and nationality or political beliefs.

The questions of appealing against the decisions on banning the entry of foreigners and stateless persons into Ukraine are being considered.

Key words: unregulated migration, legal regulation, grounds for prohibiting the entry of foreigners and stateless persons, expulsion. 